\section{International Scientific Journal Theoretical \& Applied Science}

Zafar Aktamovich Amirov

Master of Law, Senior scientific researcher at the Academy of State Governance under the President of the

Republic of Uzbekistan, (871)232-60-34, amirov.1981@mail.ru

Year: 2017 Issue: 03 Volume: 47

Published: $6.03 .2017 \quad$ http://T-Science.org

SECTION 32. Jurisprudence.

\title{
THE ROLE OF THE COURTS IN PREVENTION OF OFFENSES: IN EXAMPLE OF JUVENILES
}

\begin{abstract}
In this article, the author provides scientific-theoretical and practical analysis on the role of judicial authorities in implementation of delinquency prevention. Furthermore, the possible resolution for the goals set by the reforms in the field of law enforcement, the courts, measures taken to prevent crime rates and conditions contributing to the increase in the amount of crimes are discussed; the article also points out the importance of measures taken to suppress crime rates among the youth, especially, juvenile delinquency. According to the present article, educational activities carried out to raise the awareness of the young people are paid a serious attention; also, the courts are serving educational purposes while reviewing the cases. Besides, the article urges that despite the preventive activities, variety of law violation among the young generation are observed, such as crime of socially less importance, small crime, attempted and violent crime.

Key words: law violation, legal education, crime, court, judge, prevention of crime, suppression of crime.

Language: English

Citation: Amirov ZA (2017) THE ROLE OF THE COURTS IN PREVENTION OF OFFENSES: IN EXAMPLE OF JUVENILES. ISJ Theoretical \& Applied Science, 03 (47): 29-31.

Soi: http://s-o-i.org/1.1/TAS-03-47-6 Doi: crossef https://dx.doi.org/10.15863/TAS.2017.03.47.6
\end{abstract}

\section{Introduction}

Today the conditions that cause crime and implementing a set of measures that seek to serve in every aspect of the judicial and legal reforms can compared with the realization of the objective.

Youth in this issue, especially in prevention of juvenile offense, they carried out with the emphasis increasing educational aspect in work with youth. However, although the cases of juvenile between the different types of offenses, even if they have not only a social danger or less serious crime, but very serious types of cases leads to the commission of crimes. In most cases, a penalty against them, the current legislation is also a less strict application of sanctions, if possible, their imprisonment; with no kind of punishment procedures are clearly defined [1].

\section{Materials and Methods}

The issue of human rights violations committed by juvenile, which legal scholars J.Muxtorov that up, "youth crime prevention effective operation of the system: first, the organization of the activity of preventive services, and secondly, they are required to clearly define the objectives, thirdly, depend on ensuring internal affairs effective interaction with other departments and public bodies" [2].

The prevention of juvenile crime, it is usually based on long-term efforts to reduce the complex closely related to each other, provides for the implementation of legal measures. This activity provides by prevention education institutions, internal affairs agencies, juvenile delinquency prevention departments, committees and courts of general jurisdiction as juvenile by the subjects of special and non-special prevention.

It should be noted that youth crime prevention is one of the most important problems is that, they are under the influence of law enforcement bodies and non-governmental organizations in preventive into it after having committed the offenses. In the field of justice and healthcare as a measure of responsibility for human rights violations committed by him to avoid certain mechanisms to develop and implement more effective. It means that to prevent tort or crime is better and social useful.

One of the important issue in justice specialty is what will be the role of the judicial authorities in this aspect, and what makes the position of this government is a network of independent courts 
attention among other government bodies and law enforcement agencies.

It should be recognized that the elimination of criminal and other offenses to happen as the body directly engaged in the activity. As prevention of offenses among the youth of its population and activities are an example. A court during the criminal case, which related to juvenile delinquency, it should take concrete measures. In the case, the court appointment of a penalty against the person who committed a crime or other offense not only to justice, but he will be able to prevent other crimes.

The first reason of the main objective of criminal punishment is to train the juveniles. It means the purpose of the punishment is individual training. Typically, courts in educational role characterized as an open and transparent manner to ensure the participation of the other juvenile during their upbringing.

In this context, transparency of the legislation in court cases can be recognized as a positive condition. However, Article 19 of the Criminal Procedure Code, this is contrary to the interests of transparency, a hearing on criminal case shall be public, except for the instances inconsistent with the reasons of protection of state secrets, or connected with hearing on sexual crimes. In addition, the cases on Procedure for proceedings on the criminal cases of persons aged under eighteen at the moment of committing the offense shall be envisaged by the general rules, as well as information on the private lives of citizens or their failure to disclose the information humiliating honor and dignity of the victim, witness or other persons participating in the case, as well as the need to ensure the safety of their family members or close relatives of the cases, in other cases by the court ruling is allowed to see the closed session of the court.

Private postal and telephone correspondence can be disclosed during the open court hearing only upon the consent of the sender and receiver. Otherwise they shall be disclosed and a closed session of the court [3].

The principle in Criminal procedural law in many ways gives priority to courts, based on the facts of the case that they have the right, which allows providing hearings open or closed. However, in our opinion the proceedings in this case, for further improve the effectiveness of their activity, as well as its educational requirements of the increasing importance of the work should be open sessions of the court. Cases involving crimes committed by juvenile in closed court session in our educational process weakens a bit of a warning function. Of course, many experts in this case in open court the defendant is a juvenile as a person and the way of life may be affected by the level of its development, the statement said. However, in our view, a fair judicial process, which conducted a comprehensive and reasonable which based on the evidence and judge, it strictly comply with the above requirements and cannot be produced, then nobody would be upset, and contrariwise the juveniles who had a crime make an appropriate inference.

Therefore, the judge who makes decision should have individual approach for each case, measures to eliminate the conditions that facilitated (by way of private admonitions) degree of guilt of the defendant, there are circumstances excluding the have or not crime, as well as to explore his family condition and other cases in making the crimes and then make an appropriate inference that truly represents the obvious educational value.

In protection of the rights of juvenile Russian scientists G.I.Zabryanskiy L.V.Emelyanova emphasized that their rights and interests are more common in the activities of law enforcement agencies. According to the scientists, control activities carried out by the prosecutor's office found that the bodies of internal affairs in the process of preliminary investigation in relation to juvenile implements prison without any base evidence. This error and the violations of the law corrected in time of completion of the investigation or the court of first instance or cassation procedure [4]. Prior to that, if the duration of the preliminary investigation of the criminal case, the time of the court hearing, upheld fixes of the high court for the selected scale measure, this is a very long period and, as a result of these can lead to negative demerit in juveniles.

One of the unique features of the liability of juvenile have the limit of assigned to administrative and criminal sanctions. It means the current penalty system established by the Criminal Code of the Republic of penalties imposed on a juvenile in case 5 in 9 [5]. In prevention of crime and delinquency by these measures appropriate and evidentially carried out by the courts will serve as one of the primary factors.

According to research by A.X.Valeev, to use a suspended sentence them more efficient than sentenced to imprisonment [6]. Nevertheless, O.V.Demidova thinks that criminal liability of juvenile, $70 \%$ used a suspended sentence for their crimes during the trial period [7].

Without denying the views of the researchers listed above, it necessary to continue the practice based on liberalization of criminal sanctions which realizing in Uzbekistan as for juveniles to use less of criminal or other sanctions against persons who have committed offenses or other legal measures. However, while the inevitability of punishment of the criminal law, justice and humanitarian principles as well as the suspended sentence, taking into consider the objectives of its educational juvenile need to further strengthen the control measures during the trial time. Because the person who has committed a crime and should be serving inevitably 


\begin{tabular}{|c|c|c|c|c|c|c|}
\hline Impact Factor: & $\begin{array}{l}\text { ISRA (India) } \\
\text { ISI (Dubai, UAF } \\
\text { GIF (Australia) } \\
\text { JIF }\end{array}$ & $\begin{array}{l}=1.344 \\
=0.829 \\
=0.564 \\
=1.500\end{array}$ & $\begin{array}{l}\text { SIS (USA) } \\
\text { PИНЦ (Russia) } \\
\text { ESJI (KZ) } \\
\text { SJIF (Morocco) }\end{array}$ & $\begin{array}{l}=0.912 \\
=0.234 \\
=1.042 \\
=2.031\end{array}$ & $\begin{array}{l}\text { ICV (Poland) } \\
\text { PIF (India) } \\
\text { IBI (India) }\end{array}$ & $\begin{array}{l}=6.630 \\
=1.940 \\
=4.260\end{array}$ \\
\hline
\end{tabular}

be worthy of the punishment to the crime, and to prevent his over the edge of the penalty would be vicinity example for the other juveniles, it will be useful to determine the effectiveness of the educational effects.

The execution of inspection of internal affairs activities have significant place in realization of this the most important and profoundly serious task. It should be cooperation that is more effective and interaction between activities of citizens, selfgovernance, social organizations and governance.

\section{Conclusion}

In conclusion, it should be noted that the terms of the judicial and legal reforms in the country to further enhance the role of the courts, especially the abuse of juveniles by their crimes to further strengthen the preventive activity of any human rights violations and give appropriate legal assessment of the actions, it should need to show effect of realization of educational practice in real.

\section{References:}

1. (2015) Izox: Uzbekiston Respublikasi Zhinojat kodeksining 6-bylimi 25-26-boblari koidalari nazarda tutilmokda. Uzbekiston Respublikasi қоnun xuzhzhatlar typlami 2015 j., 23-son, 301modda, 32-son, 425-modda, 33-son, 439modda.

2. (2017) Available: http://huquqburch.uz (Accessed: 1.03.2017).

3. (2015) Uzbekiston Respublikasi konun xuzhzhatlari typlami, 2015 j., 32-son, 425modda; 33-son, 439-modda.

4. Zabrjanskij GI, Emel'janova LV (2000) Statistika prestupnosti nesovershennoletnih $\mathrm{V}$ Rossii v 1998 godu. Analiticheskij obzor. M., 2000. p. 47.
5. (2015) Izox: ZhKning 43 va 81-moddalari nazarda tutilmokda. Uzbekiston Respublikasi konun xuzhzhatlar typlami 2015 j., 23-son, 301modda, 32-son, 425-modda, 33-son, 439modda.

6. Valeev AH (2003) Uslovnoe osuzhdenie nesovershennoletnih: Avtoref. dis. ... kand. jurid. nauk. Cheljabinsk, 2003. p. 14.

7. Demidova OV (2003) Kriminologicheskaja harakteristika i preduprezhdenie prestupnosti uslovno osuzhdennyh nesovershennoletnih (po materialam Central'no-Chernozemnogo regiona Rossii): Avtoref. dis. ... kand. jurid. nauk. Volgograd, 2003. p. 3. 